\title{
Phenotypic and molecular characterisation of Brucella isolates from marine mammals
}

\author{
Claire E Dawson*1, Emma J Stubberfield ${ }^{\dagger 1}$, Lorraine L Perrett ${ }^{\dagger 1}$, \\ Amanda C King ${ }^{\dagger 1}$, Adrian M Whatmore ${ }^{\dagger 1}$, John B Bashiruddin ${ }^{1,2}$, \\ Judy A Stack ${ }^{\dagger 1}$ and Alastair P MacMillan ${ }^{\dagger 1}$
}

Address: ${ }^{1}$ Department of Statutory and Exotic Bacterial Diseases, Veterinary Laboratories Agency, New Haw, Addlestone, Surrey, KT15 3NB, UK and 'FMD Pathogenesis Group, Institute for Animal Health, Pirbright Laboratory, Ash Road, Pirbright, Woking, Surrey, GU24 ONF, UK

Email: Claire E Dawson* - c.e.dawson@vla.defra.gsi.gov.uk; Emma J Stubberfield - e.stubberfield@vla.defra.gsi.gov.uk; Lorraine L Perrett - l.l.perrett@vla.defra.gsi.gov.uk; Amanda C King - a.king@vla.defra.gsi.gov.uk; Adrian M Whatmore - a.whatmore@vla.defra.gsi.gov.uk; John B Bashiruddin - john.bashiruddin@bbsrc.ac.uk; Judy A Stack - j.a.stack@vla.defra.gsi.gov.uk; AlastairP MacMillan - brucella@clara.co.uk

* Corresponding author †Equal contributors

Published: 17 December 2008

BMC Microbiology 2008, 8:224 doi:10.1186/147I-2180-8-224

This article is available from: http://www.biomedcentral.com//47/-2/80/8/224

(c) 2008 Dawson et al; licensee BioMed Central Ltd.

This is an Open Access article distributed under the terms of the Creative Commons Attribution License (http://creativecommons.org/licenses/by/2.0), which permits unrestricted use, distribution, and reproduction in any medium, provided the original work is properly cited.

\begin{abstract}
Background: Bacteria of the genus Brucella are the causative organisms of brucellosis in animals and man. Previous characterisation of Brucella strains originating from marine mammals showed them to be distinct from the terrestrial species and likely to comprise one or more new taxa. Recently two new species comprising Brucella isolates from marine mammals, $B$. pinnipedialis and $B$. ceti, were validly published. Here we report on an extensive study of the molecular and phenotypic characteristics of marine mammal Brucella isolates and on how these characteristics relate to the newly described species.
\end{abstract}

Results: In this study, 102 isolates of Brucella originating from eleven species of marine mammals were characterised. Results obtained by analysis using the Infrequent Restriction Site (IRS)Derivative PCR, PCR-RFLP of outer membrane protein genes (omp) and IS7 I / fingerprint profiles showed good consistency with isolates originating from cetaceans, corresponding to $B$. ceti, falling into two clusters. These correspond to isolates with either dolphins or porpoises as their preferred host. Isolates originating predominantly from seals, and corresponding to B. pinnipedialis, cluster separately on the basis of IS7 I I fingerprinting and other molecular approaches and can be further subdivided, with isolates from hooded seals comprising a distinct group. There was little correlation between phenotypic characteristics used in classical Brucella biotyping and these groups.

Conclusion: Molecular approaches are clearly valuable in the division of marine mammal Brucella into subtypes that correlate with apparent ecological divisions, whereas conventional bioyping is of less value. The data presented here confirm that there are significant subtypes within the newly described marine mammal Brucella species and add to a body of evidence that could lead to the recognition of additional species or sub-species within this group. 


\section{Background}

The isolation of Brucella from marine mammals and the classical biotyping of these strains were first reported in 1994 coincidently in two locations. Ross et al. (1994) [1] reported the isolation of Brucella from tissues collected post mortem from stranded marine mammals including common seal (Phoca vitulina), harbour porpoise (Phocoena phocoena) and common dolphin (Delphinus delphis) around the coast of Scotland whilst Ewalt et al. (1994) [2] reported the recovery of the organism from an aborted foetus of a bottlenose dolphin (Tursiops truncatus) in the USA. The isolation of Brucella has since been described from a wide variety of marine mammals including Atlantic white-sided dolphin (Lagenorhynchus actus), striped dolphin (Stenella coeruleoalba), hooded seal (Crystophora cristata), grey seal (Halichoerus grypus), European otter (Lutra lutra) [3,4], Pacific harbour seal (Phoca vitulina richardsii) [5], minke whale (Balaenoptera acutorostrata) [6] and white beaked dolphin (Lagenorhynchus albirostris) [7].

Although the number of isolations of Brucella strains from marine mammals are still relatively limited, there is strong serological evidence that such infections are widespread, in prevalence, in the variety of species infected and in their geographical distribution. Evidence arising from the northern hemisphere is particularly well documented from locations such as the Scottish coast [8], the coasts of England and Wales [9], the north Atlantic Ocean, west of Iceland to the north of Norway and Russia [10], the Mediterranean Sea [11], Arctic Canada and the Atlantic coast of North America [12,13]. Evidence from the southern hemisphere is less well documented although there are reports of positive serological results from baleen whales (Mysticeti) from the western North Pacific [14], Hawaiian monk seals (Monachus schauinslandi) from the Northwestern Hawaiian Islands [15], bottlenose dolphins from the Solomon Islands [16], cetaceans living off the Peruvian coast [11] and seals from Antarctica [17] and Australia [18].

For many years, the accepted taxonomy of Brucella comprised six species: B. abortus, B. melitensis, B. suis, B. ovis, B. canis and $B$. neotomae, some of which are further divided into biovars. The attribution to species is usually made using classical biotyping techniques to identify phenotypic characteristics such as $\mathrm{CO}_{2}$ dependency, substrate utilisation, dye and antibiotic susceptibility, phage lysis, and serotyping $[19,20]$. Such phenotypic species classification relates closely to host preference and therefore this system of classification has assisted in the study of Brucella and remains widely used today for epidemiological purposes. DNA-DNA hybridization studies have demonstrated that Brucella is a highly homogeneous genus (>90\% DNA-DNA relatedness) [21-25]. Nevertheless, the development of a range of DNA based typing techniques [26-34] have supplemented the classical techniques and show remarkable correlation with the classical Brucella species.

Much attention has been focussed on attempts to classify the marine Brucella strains in a way consistent with the framework of the existing six species. Studies using classical biotyping methods revealed characteristics which were typical of the genus Brucella [19] but the pattern of which differed from those displayed by the currently recognised species $[2,4]$. In particular, the oxidative metabolism tests have allowed the differentiation of a number of distinct marine specific phenotypes [4]. Such studies resulted in a number of tentative proposals to define the Brucella isolated from marine mammals as separate species $[4,20,35,36]$ and much additional investigation has been completed in an attempt to differentiate the strains and gain insight to their evolutionary relationship with the existing recognised species. A number of early studies were carried out using classical biotyping, PCR-RFLP of the omp2a gene [37], Pulsed Field Gel Electrophoresis (PFGE) [38] and IS711 fingerprinting [6,35].

Recently, following analysis of a small number of strains, two new species names, Brucella ceti and Brucella pinnipedialis were validly published for isolates from cetaceans and pinnipeds respectively [36]. Nevertheless, the current status of the classification of Brucella isolated from marine mammals remains controversial with molecular evidence suggesting that $B$ ceti comprises two genetic clusters $[32,39,40]$. This study aims to characterise Brucella isolates from a range of marine mammals originating from various geographical locations using a selection of widely recognised classical and molecular techniques in direct comparison. The data generated may assist in resolving some of these taxonomic issues and gives the most extensive description to date of the characteristics of this group of isolates.

\section{Results}

A comparative summary of the results of characterisation of all 102 isolates by both phenotypic and molecular approaches is provided in Table 1 (Additional file 1.)

\section{Molecular characterisation \\ PCR-RFLP of omp genes}

Analysis of the 102 isolates examined in this study generated six unique profiles. Of the six profiles $\mathrm{M}(\mathrm{J})$ was the most common being present in 53/102 isolates. This profile was predominantly associated with porpoises $(79 \%$ of isolates) but was also less frequently seen in dolphins (15\%), seals (4\%) and whales (2\%). Of the remaining five profiles, $\mathrm{N}(\mathrm{K})$ was exclusively associated with dolphins 
while profiles $\mathrm{L}(\mathrm{I})$ and $\mathrm{O}(\mathrm{I})$ were predominantly associated with seals (95\% and $83 \%$ of isolates respectively). Two less commonly observed profiles, $\mathrm{P}(\mathrm{I})$ and $\mathrm{Q}(\mathrm{I})$, were seen only in hooded seal isolates and in a single isolate from a bottlenose dolphin respectively.

\section{IS7 I I fingerprinting}

IS711 fingerprinting analysis of the 102 isolates generated 17 unique marine-specific IS711 profiles of which 13 were observed amongst the European strains and four amongst the USA strains. All fingerprints comprised more than 20 bands and examples of each profile are shown in Figure 1. The distribution of IS711 copies in the genomes of all of the marine strains included in this study showed little resemblance to any pattern previously observed in any other species or biovars, including those of B. ovis or B. suis bv 2 which themselves have many copies of the element. Clustering of the 17 fingerprints divided them into 4 groups (labelled clusters $1-4$ ) when using a cut-off value of $>85 \%$ similarity. Members of cluster 1 were isolates predominantly associated with seals possessing omp pattern $\mathrm{L}(\mathrm{I})$ or $\mathrm{O}(\mathrm{I})$. Members of cluster 2 were isolates predominantly associated with porpoises possessing omp pattern $\mathrm{M}(\mathrm{J})$. Members of cluster 3 were isolates of omp pattern $\mathrm{N}(\mathrm{K})$ exclusively associated with dolphins. Cluster 4 isolates, representing omp pattern $\mathrm{P}(\mathrm{I})$, were associated only with hooded seals.

\section{IRS-Derivative PCR}

The ISR-Derivative PCR examines the presence/absence of four distinct PCR fragments in isolates. Positive results for PCRs II and III were always congruent with each other and with IS711 fingerprinting cluster 2, comprising of predominantly porpoise isolates. PCR IV was positive only in the group exclusively associated with dolphins corresponding to IS711 fingerprinting cluster 3. PCR I appeared to be specific for strains predominantly originating from seals (IS711 fingerprinting clusters 1 and 4). Four isolates repeatedly failed to provide a product with any of the PCRs. These were 3 isolates from IS711 fingerprinting cluster 1 all originating from the USA and a single hooded seal isolate from the UK.

\section{Phenotypic characterisation}

Classical bacteriological biotyping techniques to identify phenotypic characteristics have traditionally been used to classify Brucella strains. Although these techniques have proved useful, they are subjective and it is well recognised that some strains may give unexpected or anomalous results to some or all of the tests.

\section{$\mathrm{CO}_{2}$ requirement}

In this study, isolates originating from seals (corresponding to IS711 fingerprinting cluster 1) in general showed a requirement for $\mathrm{CO}_{2}$ for growth whereas isolates from

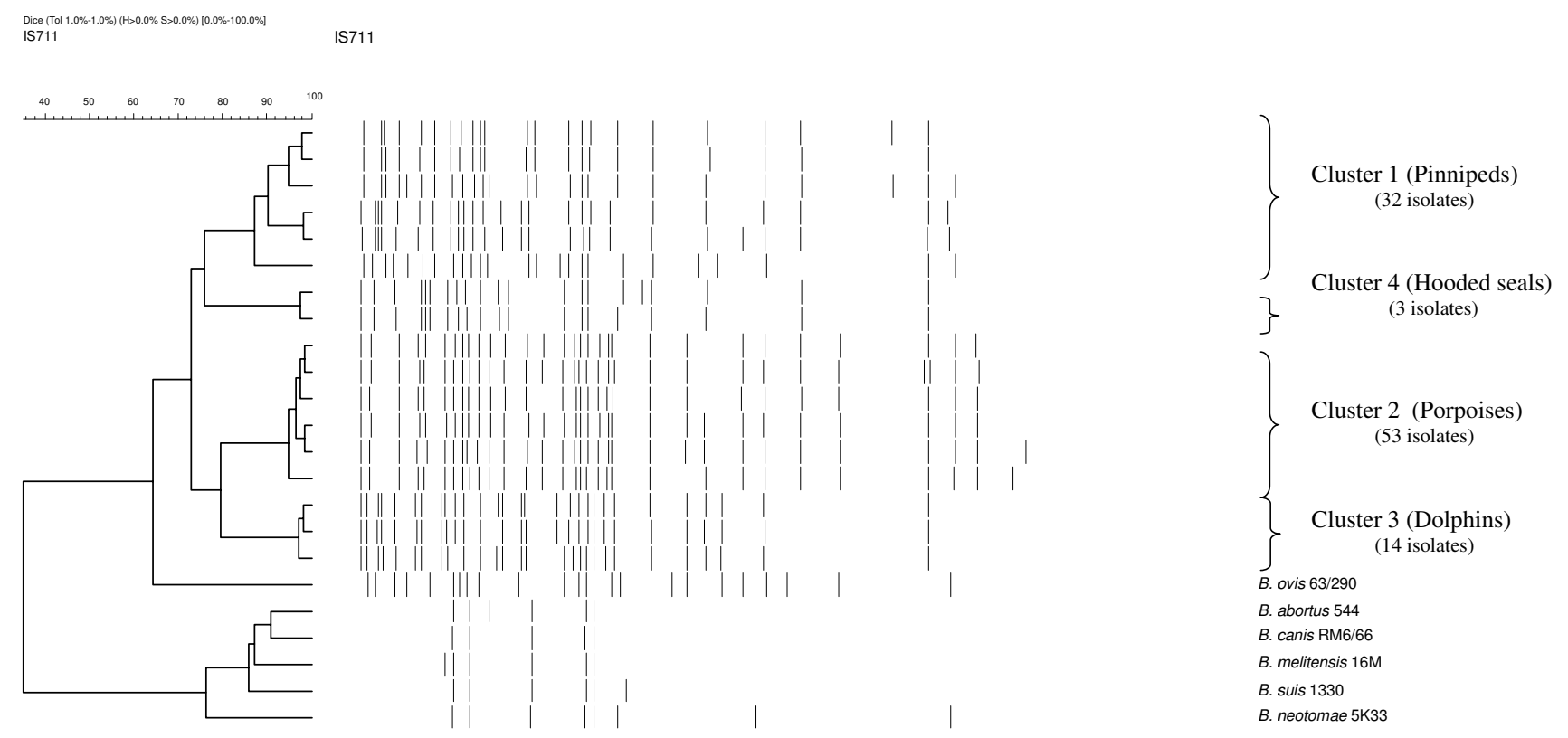

Figure I

Representation of examples of full IS7 I I fingerprints of Brucella isolates from marine mammal and reference strains. 
cetaceans (IS711 fingerprinting clusters 2 and 3) generally did not. However several exceptions were observed (Table 1, Additional file 1).

\section{Agglutination with $A$ and $M$ monospecific antisera}

Serotyping with $A$ and $M$ monospecific antisera is very subjective and it is well recognised that apparently anomalous results are observed. In addition, strains converting to the rough phenotype on subculture may lose the characteristic. The majority of isolates were A dominant only but some strains agglutinated both $\mathrm{A}$ and $\mathrm{M}$ antisera. These strains did not correspond to a single molecular type, but were distributed throughout the molecular groups discussed above. None of the isolates originating from the USA agglutinated with either the A or M monospecific serum (Table 1, Additional file 1).

\section{Phage lysis}

Smooth Brucella strains are lysed by specific phages, and the pattern of lysis is an important characteristic which has been used to classify terrestrial strains, although the characteristic may be lost if the strains become rough on subculture. Phage lysis results among the panel examined here were very variable with no clear patterns correlating to the groups identified by the various molecular typing methods. The majority of isolates (from all IS711 fingerprinting clusters) were lysed by phage $\mathrm{Bk}_{2}$ and of the isolates that showed any lytic activity only three isolates (29, 34 and 102) from IS711 fingerprinting clusters 1 and 2 were not lysed by this phage. Sixty six (65\%) of isolates were lysed by Wb phage, forty-eight (47\%) were lysed by Fi phage and eleven (11\%) of isolates were lysed by $\mathrm{Tb}$ phage. A total of six isolates all originating from IS711 fingerprinting cluster 2 showed no lysis by any of the phages.

\section{Dye sensitivity}

The vast majority of isolates were not inhibited by basic fuchsin or thionin. A few isolates of IS711 fingerprinting cluster 2 were inhibited by both fuchsin and thionin $(7$, $10,15)$ or only by fuchsin $(9,20)$.

\section{Discussion}

Data from a large comparative analysis of molecular and phenotypic characteristics of marine mammal Brucella is presented here. The 102 strains included in this study are derived from the North Atlantic from locations around the coasts of the UK, France, Spain, Germany, and Norway. Although they are predominantly European in origin a small number of North American isolates are also included in this study and two from the Pacific ocean. Wherever serological surveys have been carried out, a high prevalence has been found in Pacific waters $[11,17,18]$. In addition, a strain isolated from a human brucellosis case in New Zealand gave test results indistinguishable from one of the marine mammal strains (97) included in this study originating from a bottlenose dolphin from the USA [41]. Recent analysis of two further historical cases of severe human brucellosis originating in Peru [42] also revealed that both associated isolates share the same genotype [43]. These findings indicate that marine mammal Brucella isolates may also be common in parts of the world where little data has yet been reported. Until recently molecular evidence suggested that Brucella originating from marine mammals from the Pacific ocean all belonged to $B$. pinnipedialis $[41,44]$. However, a recent report provides evidence that strains belonging to $B$. ceti are present [45]. This report is also corroborated by our own studies (unpublished data).

When considered in full, the data obtained in this study reveals a remarkable congruence between groups identified by different molecular tests and with the order and/or species of marine mammal from which they originated. These relationships are depicted graphically in Figure 2. Thus, when considering IS711 fingerprints, four main clusters were identified. Within the numerically largest of these clusters, cluster 2, all isolates possess omp PCR-RFLP pattern $\mathrm{M}(\mathrm{J})$, and display the IRS-PCR profile -++- . The vast majority of these strains originate from harbour porpoises. In contrast members of IS711 fingerprinting cluster 3 all possess omp PCR-RFLP profile N(K) and IRS-PCR profile - - + . Without exception these isolates originate from dolphins. Thus cetacean isolates appear to fall into two well-separated clusters with different preferred hosts that are consistently apparent using different molecular approaches. These isolates correspond to the newly described species $B$. ceti.

Isolates that are members of IS711 fingerprinting cluster 1 correspond to two main omp PCR-RFLP profiles L(I) and $\mathrm{O}(\mathrm{I})$. The vast majority of these isolates possess IRS-PCR profile + - - , although three isolates within this group, originating from the Atlantic coast of the USA, reacted with none of the IRS-PCR primer sets (profile - - - -). A single isolate also possesses a unique omp PCR-RFLP profile $\mathrm{Q}(\mathrm{I})$. Members of this IS711 fingerprinting cluster were predominantly isolated from seals and correspond to the recently described $B$. pinnipedialis. Three isolates obtained from hooded seals comprised IS711 fingerprinting cluster 4. These three isolates also possess a unique omp PCRRFLP profile $\mathrm{P}(\mathrm{I})$ and, as with members of IS711 fingerprinting cluster 1 possess IRS-PCR profiles + - - - or - - - -

Thus, the overall finding of four groups identified using a cut-off value of $>85 \%$ similarity to define IS711 fingerprinting clusters is consistent with other molecular tests and with host preferences observed in this study. Furthermore, the grouping of strains in this study is consistent with other recent studies. Studies based on genome mapping recently divided marine mammal Brucella strains 

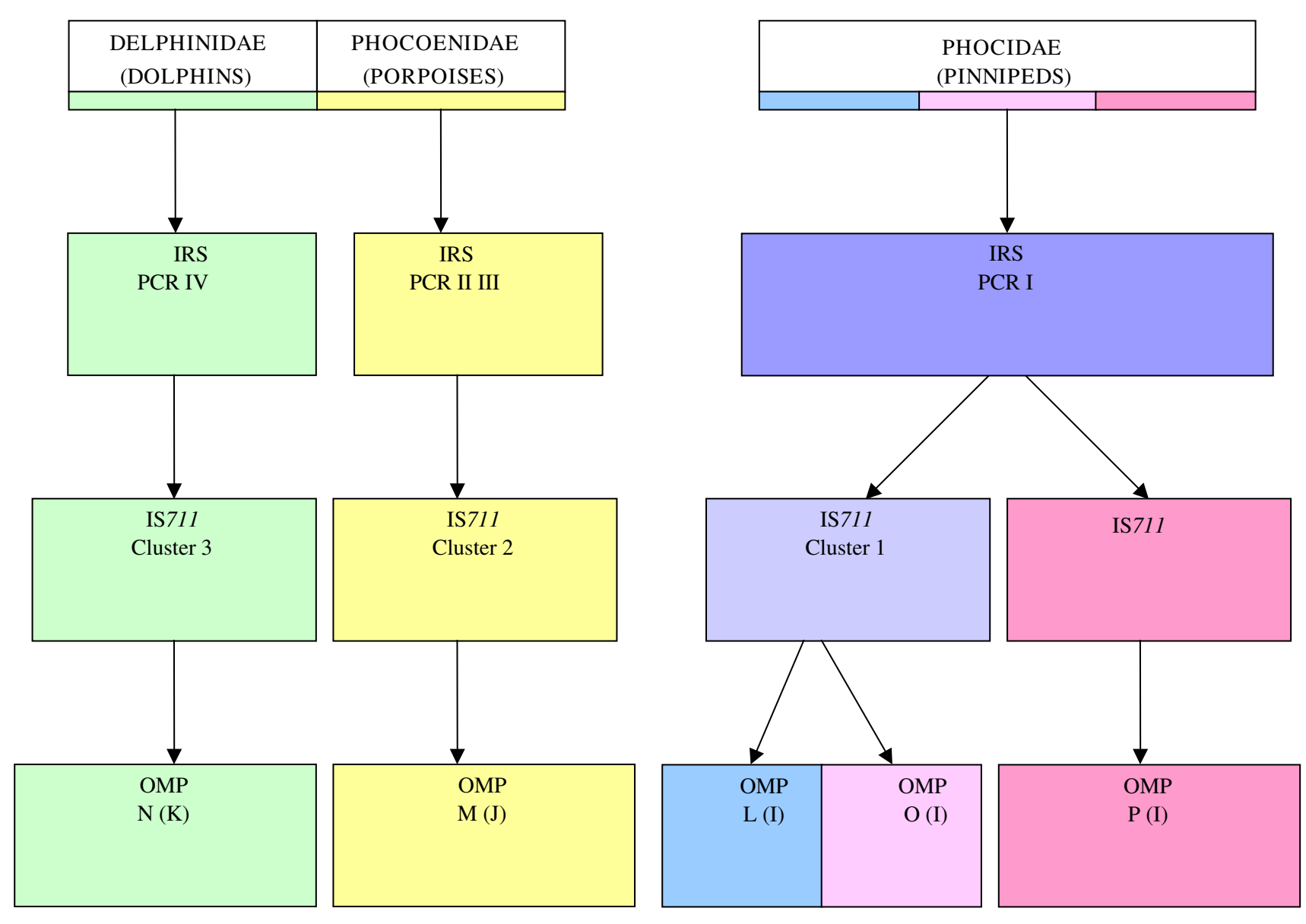

\section{Figure 2}

Summary of relationships between Brucella isolates based on molecular tests. This schematic is based on observations of strains isolated from European waters as too few isolates from elsewhere have been received to date to reach reliable conclusions.

into three major groups [40]. Strains originating from seals fell into one group (Group I), with a single hooded seal isolate placed within this group, although possessing a variant profile. As in this study isolates from cetaceans fell into two distinct groups comprising isolates from common and striped dolphins (Group II) and isolates predominantly from harbour porpoises (Group III). The authors of this article suggested that, given the large branch lengths between the three groups, they could be classified as separate species. Moreover, a recent comparative study using Variable-Number-of Tandem-Repeats (VNTR) analysis and multilocus sequence analysis (MLSA) divides strains into the same three groups [39]. This study identified congruent VNTR and MLSA groups corresponding to isolates with preferred hosts of dolphins, porpoises and seals. Furthermore, within the seal group isolates from hooded seals formed a subgroup, as seen in this study, and isolate 97 , corresponding to the isolate with a distinct $o m p$ PCR-RLP profile, was found to represent a unique sequence type and form a separate sub- branch within the group based on VNTR clustering. While agreeing with the validity of a species group comprising of seal isolates and now classified as $B$. pinnipedialis, the authors of this manuscript questioned the validity of the group since published as $B$. ceti. This was based on the clear division into two groups with distinct host specificities that appeared less closely related to each other than either was to the group of seal isolates now classified as $B$. pinnipedialis.

While there was clear division into consistent groups based on molecular typing in combination with apparent host preferences there was little evidence of any consistent phenotypic traits based on the conventional biotyping procedures usually applied to Brucella. Although classical bacteriological typing has been universally used for identifying and characterising Brucella strains isolated from terrestrial mammals, the results obtained in this study were disappointing. It is well recognised that such methods require considerable skill and expertise and correctly 
standardised reagents to carry out, that their interpretation is somewhat subjective, and that anomalous results are not uncommon. However, the results of phage lysis, sensitivity to dyes and agglutination with monospecific sera showed no evidence of any grouping patterns that corresponded to host of origin or the molecular groups described above. The results observed in this study suggest that these tests offer little value in the characterisation of marine mammal strains. The strongest correlation was with the requirement of $\mathrm{CO}_{2}$ for growth. In general, isolates derived from seals required additional $\mathrm{CO}_{2}$ for growth, but isolates from cetaceans did not, although there were exceptions. This is in agreement with the observations of Foster et al. (2007) [36] in the description of $B$. ceti and B. pinnipedialis. However, a number of other characteristics outlined in the species descriptions are not entirely consistent with the data presented here. Thus, both $B$. ceti and B. pinnipedialis are described as A antigen dominant but isolates included in this study, corresponding to both of these species, react with monospecific sera to both $A$ and $M$ antigens. Furthermore isolates of $B$. cet $i$ are described as being lysed by $\mathrm{Wb}$ phage but not lysed by Tb phage. However, in this study we found exceptions to this description for both $\mathrm{Wb}$ phage (in IS711 fingerprinting cluster 2 isolates) and Tb phage (in both IS711 fingerprinting clusters 2 and 3) with reproducible results. Similarly isolates of $B$. pinnipedialis are described as being lysed by Wb phage with 'a small number' of isolates being lysed by $\mathrm{Tb}$ phage. While results reported here agree with the latter observation there are many examples in this study of isolates corresponding to $B$. pinnipedialis not being lysed by Wb phage (IS711 fingerprinting cluster 1).

\section{Conclusion}

This study represents the most extensive characterisation of marine mammal strains, based on traditional Brucella bioyping approaches and molecular approaches, carried out to date. The marine mammal Brucella strains described in this paper could readily be distinguished from terrestrial Brucella species using omp PCR-RFLP, IS711 fingerprinting, and IRS-derivative PCR. However, characteristic profiles based on conventional biotyping were not apparent. Using molecular methods, strains fell into rational groups, with good congruence between methods and with the preferred host. Strains originating from cetaceans clearly fall into two groups with either dolphins or porpoises as their preferred host. These findings are consistent with previous suggestions, based on other molecular evidence $[39,40]$, that the recently described species $B$. ceti could be further subdivided. Strains from seals fell into one major group corresponding to the recently described species $B$. pinnipedialis. However, a small number of strains examined from hooded seals, while clustering most closely to $B$. pinnipedialis, were quite distinct from the other seal strains using omp PCR-RFLP and IS711 fingerprinting. Again this is consistent with observations elsewhere $[39,40]$ and suggests that there are also further ecological subdivisions within pinniped $\mathrm{Bru}$ cella isolates. While a large number of isolates were characterised in this study, their geographical distribution is limited, and it is clear that much more extensive and global surveillance is required in order to fully understand the distribution, ecology and genetic relatedness of Brucella isolates from marine mammals.

\section{Methods \\ Brucella isolates}

A total of 102 Brucella strains isolated from marine mammals were included in this study. Cetacean isolates included organisms obtained from 42 harbour porpoises, seven Atlantic white-sided dolphins, one white-beaked dolphin, three bottlenose dolphins, four common dolphins, eight striped dolphins, two minke whales, and one unspecified dolphin species. Pinniped isolates included organisms originating from 22 common seals, three grey seals, three hooded seals and five unspecified seals. A single isolate originating from a European otter was also included. Reference and type strains of currently recognised species of Brucella used in this study were all obtained from the VLA culture collection. All isolates had previously been lyophilized and stored at $2-8^{\circ} \mathrm{C}$. The isolates were subcultured onto serum dextrose agar (SDA) plus $10 \%$ equine serum and incubated at $37^{\circ} \mathrm{C}$ for 3 to 5 days in the presence of additional $10 \% \mathrm{CO}_{2}$.

\section{Classical biotyping}

Phenotypic characterisation of the isolates was carried out using internationally recognised classical biotyping methods including the requirement for additional $\mathrm{CO}_{2}$ for growth, sensitivity to aniline dyes, serotyping using A and M monospecific sera and phage typing $[19,20]$.

\section{Preparation of genomic DNA}

Genomic DNA was prepared from 3-4 day old cultures on SDA as described previously [29].

\section{PCR-RFLP of omp2a, omp2b and omp25 genes}

PCR-RFLP of the genes encoding outer membrane proteins Omp2a, Omp2b and Omp25 was conducted essentially according to the method described by Cloeckaert et al., (1995) [28]. Brucella reference strains were included to maintain consistency of pattern nomenclature (data not shown). PCR products were digested with enzymes previously shown to discriminate within the marine mammal Brucella. Thus omp25 was digested with EcoRV, omp2a was digested with HinfI and KpnI, while omp2b PCR products were digested with BglII, TaqI, HaeIII, HinfI, KpnI, and EcoRI. PCR products of isolates that possessed the O(I) profile were further treated with the enzyme AluI in order to differentiate them from the $\mathrm{P}(\mathrm{I})$ group. RFLP profiles of the closely related $o m p 2 \mathrm{a}$ and $2 \mathrm{~b}$ genes of each Brucella reference strain have been analysed and described previously 
$[28,46]$. These papers used the letters A through to K to represent each profile with each letter representing a certain combination of restriction patterns with the restriction enzymes used. This study uses and extends this profile naming scheme, but where novel patterns have been discovered the lettering has been continued consecutively and the profiles are named in the format $\mathrm{X}(\mathrm{Y})$. X $(\mathrm{Y})$ represents the combination of the individual restriction patterns of omp 2a and 2b genes with the omp2a gene profiles shown in parenthesis.

\section{IS7 I I fingerprinting}

The mobile genetic element IS711 has proven a useful target for molecular characterisation based on the number and distribution of IS711 copies within the bacterial genomes. A digoxigenin-labelled IS711 probe was generated using primers sequences 5' GACCAAGCTGCATGCTG 3' and 5' TGCGAGATGGACGAAGC 3' derived from methods and sequences previously described by Halling et al., (1993) [47] and Ouahrani et al (1993) [27]. Genomic DNA from each strain was incubated at $37^{\circ} \mathrm{C}$ for 3 hours with $40 \mathrm{U}$ of EcoRI (Promega) before electrophoresis through a $0.8 \%(\mathrm{w} / \mathrm{v})$ agarose gel at $50 \mathrm{~V}$ overnight. The fragments were transferred to Hybond-N nitrocellulose (Amersham Pharmacia Biotech) using a vacuum blot (BioRad) and hybridised overnight at $65^{\circ} \mathrm{C}$ with the labelled IS711 probe. The hybridised probe was detected using alkaline phosphatase labelled anti-digoxigenin antibody (Roche). Reaction with the chemiluminescent substrate (CSPD) (Roche) was measured by exposure to X-ray film (Amersham). RFLP profiles were analysed using Bionumerics (Version 4.5, Applied Maths) using the following tolerance settings: optimisation $0 \%$, and position tolerance $1 \%$. Profiles were clustered using Dice's coefficients and the UPGMA approach.

\section{IRS-Derivative PCR}

Strains in this study were analysed by a derivative of the Infrequent Restriction Site-PCR (IRS-PCR), using a method described by Cloeckaert et al., (2003) [48]. Primers designed for PCRs II, III, and IV contain portions of the IS711 element and are intended to be specific for cetacean isolates. PCR I is intended to be specific for isolates from seals.

\section{Authors' contributions}

CD carried out the omp PCR RFLP and IRS-Derivative PCR studies and drafted the manuscript. ES carried out the IS711 fingerprinting studies. LP carried out the classical typing. JS, JB and AW helped draft the manuscript. AM conceived of the study, and participated in its design and coordination and helped to draft the manuscript. AK participated in the omp PCR RFLP and IRS-Derivative PCR studies. All authors read and approved the final manuscript.

\section{Additional material}

\section{Additional File 1}

Test results of strains included in the study. The data provided shows phenotypic and molecular characterisation of marine mammal isolates included in this study. ${ }^{1}$ PCR I, specific for isolates from pinnipeds. PCR II, III and IV specific for isolates from cetaceans. ${ }^{2}$ Overall endonuclease restriction pattern profiles of omp $2 a$ gene and $2 b$ gene with omp $2 a$ gene profiles shown in parenthesis. ${ }^{3}$ Berkeley Webridge $L=L y s i s ~ N L=N o .{ }^{4}$ Webridge $L=$ Lysis $N L=$ No. ${ }^{5}$ Firenze Webridge $L=L y$ sis $N L=$ No. ${ }^{6}$ Tibilisi Webridge $L=$ Lysis $\mathrm{NL}=$ No. ${ }^{7} \mathrm{CO}_{2}$ requirement. ${ }^{8}$ Basic fuchsin at $20 \mathrm{l} / \mathrm{ml}(1 / 50,000 \mathrm{w} / \mathrm{v}) .{ }^{9}$ Thionin at $20 \mathrm{l} / \mathrm{ml}(1 / 50,000 \mathrm{w} / \mathrm{v}) .{ }^{10}$ Agglutination with monospecific sera. ${ }^{11}$ Location At $=$ Atlantic ocean, $\mathrm{Pa}$ = Pacific ocean .

Click here for file

[http://www.biomedcentral.com/content/supplementary/1471-

2180-8-224-S1.doc]

\section{Acknowledgements}

The authors would like to thank the following for the supply of isolates: G. Foster (Scottish Agricultural College, SAC, Inverness, UK), D. Henderson (Scottish Agricultural College SAC, Perth, UK), P. Jepson (Institute of Zoology), Veterinary Laboratories Agency, Penrith (Cumbria, UK), C. Watson (Department of Agriculture and Rural Development DARDNI), J. Godfroid (Department de Bacteriologie et Immunologie, INRV, Belgium), B. GarinBastuji (Agence Française de Sécurité Sanitaire des Ailments, AFSSA, France), Withheld (Germany), C. Marin (Centro de Investigatión y Tecnologia Agroalimentaria de Aragon, CITA, Spain), D. Ewalt (National Veterinary Services Laboratories, NVSL Ames, USA) and for the supply of material: N. Davison and V. Simpson (Veterinary Laboratories Agency, Truro, UK)

\section{References}

I. Ross HM, Foster G, Reid RJ, Jahans KL, MacMillan AP: Brucella species infection in sea-mammals. Vet Rec 1994, 1 34:359.

2. Ewalt DR, Payeur JB, Martin BM, Cummins DR, Miller WG: Characteristics of a Brucella species from a bottlenose dolphin (Tursiops truncatus). J Vet Diagn Invest 1994, 6:448-452.

3. Foster G, Jahans KL, Reid RJ, Ross HM: Isolation of Brucella species from cetaceans, seals and an otter. Vet Rec 1996, I38:583-586.

4. Jahans KL, Foster G, Broughton ES: The characterisation of Brucella strains isolated from marine mammals. Vet Microbiol 1997, 57:373-382.

5. Garner MM, Lambourn DM, Jeffries SJ, Hall PB, Rhyan JC, Ewalt DR, Polzin LM, Cheville NF: Evidence of Brucella infection in Parafilaroides lungworms in a Pacific harbor seal (Phoca vitulina richardsii). J Vet Diagn Invest 1997, 9:298-303.

6. Clavareau C, Wellemans V, Walravens K, Tryland M, Verger JM, Grayon M, Cloeckaert A, Letesson JJ, Godfroid J: Phenotypic and molecular characterization of a Brucella strain isolated from a Minke Whale (Balaenoptera acutorostrata). Microbiology 1998, 144:3267-3273.

7. Foster G, MacMillan AP, Godfroid J, Howie F, Ross HM, Cloeckaert A, Reid RJ, Brew S, Patterson IAP: A review of Brucella sp. infection of sea mammals with particular emphasis on isolates from Scotland. Vet Microbiol 2002, 90:563-580.

8. Ross HM, Jahans KL, MacMillan AP, Reid RJ, Thompson PM, Foster G: Brucella species infection in North Sea seal and cetacean populations. Vet Rec 1996, 138:647-648.

9. Jepson PD, Brew S, MacMillan AP, Baker JR, Barnett J, Kirkwood JK, Kuiken T, Robinson IR, Simpson VR: Antibodies to Brucella VR:in marine mammals around the coast of England and Wales. Vet $\operatorname{Rec} 1$ 1997, 141:513-515. 
10. Tryland M, Kleivane L, Alfredson A, Kjeld M, Arnason A, Stuen S Godfroid J: Evidence of Brucella infection in marine mammals in the North Atlantic Ocean. Vet Rec 1999, I 44:588-592.

II. VanBressam MF, van Waerebeek K, Raga JA, Godfroid J, Brew SD, MacMillan AP: Serological evidence of Brucella species in odontocetes from the south Pacific and the Mediterranean. Vet Rec 200I, I48:657-66I.

12. Nielsen O, Nielsen K, Stewart REA: Serological evidence of Brucella spp. Exposure in Atlantic walruses (Odobenus rosmarus rosmarus) and ringed seals (Phoca hispida) of Arctic Canada. Arctic 1996, 49:383-386.

13. Nielsen O, Stewart REA, Nielsen K, Measures L, Duignan P: Serological survey of Brucella spp. antibodies in some marine mammals of North America. J Wildlife Dis 200I, 37:89-100.

14. Ohishi K, Zenitani R, Bando Takeharu, Goto Y, Uchida K, Maruyama T, Yamamoto S, Miyazaki N, Fujise Y: Pathological and Serological evidence of Brucella-infection in baleen whales (Mysticeti) in the western North Pacific. Comp Immunol Microb 2003 26: $125-136$.

15. Nielsen O, Nielsen K, Braun R, Kelly L: A comparison of four serologic assays in screening for Brucella exposure in Hawaiian monk seals. J Wildl Dis 2005, 4 I(I): I 26-I33.

16. Tachibana M, Watanabe K, Kim S, Omata Y, Murata K, Hammond T, Watarai M: Antibodies to Brucella spp. in Pacific Bottlenose Dolphins from the Solomon Islands. J Wildl Dis 2006, 42(2):4|2-4|4.

17. Retamal P, Blank O, Abalos P, Torres D: Detection of anti-Brucella antibodies in pinnipeds from the Antarctic territory. Vet Rec 2000, I46:166-167.

18. Dawson CE: Anti-Brucella antibodies in pinnipeds of Australia. Microbiology Aust 2005, 26:87-89.

19. Alton GG, Jones LM, Angus RD, Verger JM: Techniques for the Brucellosis Laboratory. Institut National de la Recherche Agronomique, Paris 1988.

20. Corbel MJ, Brinley-Morgan WJ: Genus Brucella Meyer and Shaw 1 920. I 73AL. In Bergey's Manual of Systematic Bacteriology Volume I. Edited by: Krieg NR, Holt JG. The Williams and Wilkins Co., Baltimore; 1984:377-388.

21. Hoyer BH, McCullough NB: Polynucleotide homologues of Brucella deoxyribonucleic acids. J Bacteriol 1968, 95:444-448.

22. Hoyer BH, McCullough NB: Homologues of deoxyribonucleic acids from Brucella ovis, canine abortion organisms and other Brucella species. J Bacteriol I968, 96: I783-I790.

23. Verger JM, Grimont F, Grimont PAD, Grayon M: Brucella a monospecific genus as shown by deoxyribonucleic acid hybridisation. Int J Syst Bacteriol 1985, 34:292-295.

24. Verger JM, Grimont F, Grimont PAD, Grayon M: Taxonomy of the genus Brucella. Ann Ins Pasteur Microbiol 1987, I38:235-238.

25. De Ley J, Mannheim W, Seyers P, Lievens A, Densin M, Vanhoucke M, Gillis M: Ribosomal ribonucleic acid astron similarities and taxonomic neighbourhood of Brucella and CDC Group. Int J Syst Bacteriol 1987, 37:35-42.

26. Bricker J, Halling SM: Differentiation of Brucella abortus bv. I, 2, and 4, Brucella melitentis, Brucella ovis, and Brucella suis bv. I by PCR. J Clin Microbiol I994, 32:2660-2666.

27. Ouahrani S, Michaux S, Widada JS, Bourg G, Tournebize R, Ramuz M, Liautard JP: Identification and sequence analysis of IS650I, an insertion sequence in Brucella spp.: relationship between genomic structure and number of IS650 I copies. J Gen Microbiol 1993, I39:3265-3273.

28. Cloeckaert A, Verger JM, Grayon M, Grepinet O: Restriction site polymorphism of the genes encoding the major $25 \mathrm{kDa}$ and $36 \mathrm{kDa}$ outer membrane proteins of Brucella. Microbiology |995, |41:2|||-2|2|.

29. Whatmore AM, Murphy TJ, Shankster S, Young E, Cutler SJ, MacMillan AP: Use of Amplified Fragment Length Polymorphism to identify and type Brucella isolates of medical and veterinary interest. J Clin Microbiol 2005, 43:76I-769.

30. García-Yoldi D, Marín CM, de Miguel MJ, Muñoz PM, Vizmanos JL, López-Goñi I: Multiplex PCR assay for the identification and differentiation of all Brucella species and the vaccine strains Brucella abortus SI 9 and RB5I and Brucella melitensis REVI. Clin Chem 2006, 52:779-78I.

31. Ratushna V, Sturgill D, Ramamoorthy S, Reichow S, He Y, Lathigra R, Sriranganathan N, Halling S, Boyle S, Gibas C: Molecular targets for rapid identification of Brucella spp. BMC Microbiol 2006, 6: I3.
32. Whatmore M, Perrett L, MacMillan AP: Characterisation of the genetic diversity of Brucella by multilocus sequencing. $B M C$ Microbiol 2007, 7:34.

33. Le Flèche $P$, Jaques I, Grayon $M, A$ I Dahouk $S$, Bouchon $P$, Denoeud F, Nöckler K, Neubauer H, Guilloteau LA, Vergnaud G: Evaluation and selection of tandem repeat loci for a Brucella MLVA typing assay. BMC Microbiol 2006, 6:9.

34. Whatmore AM, Shankster SJ, Perrett LL, Murphy TJ, Brew SD, Thirlwall RE, Cutler SJ, MacMillan AP: Identification and characterisation of Variable-Number Tandem-Repeat markers for typing of Brucella spp. J Clin Microbiol 2006, 44: I982-1993.

35. Bricker BJ, Ewalt DR, MacMillan AP, Foster G, Brew S: Molecular characterization of Brucella strains isolated from marine mammals. J Clin Microbiol 2000, 38: I 258- I 262

36. Foster G, Osterman BS, Godfroid J, Jacques I, Cloeckaert A: Brucella ceti sp. nov. and Brucella pinnipedialis sp. nov. for Brucella strains with cetaceans and seals as their preferred hosts. Int | Syst Evol Microbiol 2007, 57:2688-2693.

37. Miller WG, Adams LG, Ficht TA, Cheville NF, Payeur JP, Harley DR, House C, Ridgeway SH: Brucella - induced abortions and infections in bottlenose dolphins (Tursiops truncatus). J Zoo Wildlife Med 1999, 30:100-I I0.

38. Jensen AE, Cheville NF, Thoen CO, MacMillan AP, Miller WG: Genomic fingerprinting and development of a dendrogram for Brucella spp. isolated from seals, porpoises and dolphins. J Vet Diagn Invest 1999, I I: I 52- I 57.

39. Groussaud P, Shankster S, Koylass MS, Whatmore AM: Molecular typing divides marine mammal strains of Brucella into at least three groups with distinct host preferences. J Med Microbiol 2007, 56: I512-1518.

40. Bourg $\mathrm{G}, \mathrm{O}^{\prime}$ Callaghan $\mathrm{D}$, Boschiroli ML: The genomic structure of Brucella strains isolated from marine mammals gives clues to evolutionary history within the genus. Vet Microbiol 2007, I 25:375-80.

4I. McDonald WL, Jamaludin R, Macereth G, Hansen M, Humphrey S, Short P, Taylor T, Swingler J, Dawson CE, Whatmore AM, Stubberfield E, Perrett LL, Simmons G: Characterisation of a Brucella sp. strain as a marine-mammal type despite isolation from a patient with spinal osteomyelitis in New Zealand. J Clin Microbiol 2006, 44:4363-4370.

42. Sohn A, Probert A, Glaser C, Gupta N, Bollen A, Wong J, Grace E, McDonald W: Human neorobrucellosis with intracerebral granuloma caused by a marine mammal Brucella spp. Emerg Infect Dis 2003, 9(4):485-488.

43. Whatmore AM, Dawson $C$, Groussaud $P$, Koylass $M$, King A Shankster S, Sohn A, Probert W, McDonald W: A marine mammal Brucella genotype associated with zoonotic infection. Emerg Inf Dis 2008, 14:517-518.

44. Ohishi K, Takishita K, Kawato M, Zenitani R, Bando T, Fujise Y, Goto $Y$, Yamamoto S, Maruyama T: Molecular evidence of new variant Brucella in North Pacific common minke whales. Microbe Infect 2004, 6: I199-1204.

45. Hernández-Mora G, González-Barrientos R, Morales J-A, ChavesOlarte E, Guzmán-Verri C, Baquero-Calvo E, De-Miguel M-J, Marin C$M$, Blasco J-M, Moreno E: Neorobrucellosis in stranded dolphins, Costa Rica. Emerg Infect Dis 2008, I 4: |430-|433.

46. Cloeckaert A, Verger J-M, Grayon M, Paquet J-Y, Garin-Bastiji B, Foster G, Godfroid ]: Classification of Brucella spp. isolated from marine mammals by DNA polymorphism at the omp2 locus. Microbe Infect 200I, 3:729-738.

47. Halling SM, Tatum FM, Bricker BJ: Sequence and characterisation of an insertion sequence, IS7 I I, from Brucella ovis. Gene I993, 133:|23-127.

48. Cloeckaert A, Grayon M, Grepinet O, Bourmedine KS: Classification of Brucella strains isolated from marine mammals by infrequent restriction site-PCR and development of specific PCR identification tests. Microbe Infect 2003:593-602. 